\title{
Article
}

\section{Family knowledge of population issues}

\author{
Mujahidatul Musfiroh, ${ }^{1}$ Retno Setyowati, ${ }^{1}$ Yeremia Rante Ada, ${ }^{1}$ Sholahuddin Sholahuddin, ${ }^{1}$ \\ Najib Najib ${ }^{2}$ \\ ${ }^{1}$ Center for Population and Gender Studies, LPPM UNS, Surakarta; ${ }^{2}$ National Population and Family Planning \\ Board (BKKBN) of Central Java, Semarang, Indonesia
}

\begin{abstract}
Background: The population growth rate of Central Java Province is considerably above the ideal. Therefore, the Provincial and Regional Governments need to carefully plan the development programs by analyzing the family knowledge of population issues. This study aims to determine the family knowledge of population issues.

Design and Methods: This research used the secondary data analysis (SDA) method. The data were taken from the 2019 Performance and Program Accountability Survey (SKAP) of the Population of KKBPK (Population of Family Planning and Family Development), Central Java Province. The data included in the 2019 SKAP Keluarga on population issues will be analyzed using descriptive quantitative analysis.

Results: According to the research data, $51.5 \%$ of respondents understood population issues. The commonly recognized issues are unemployment $(95.5 \%)$, employment $(97.1 \%)$, and poverty (97.1\%). The source of information widely used by respondents is the television (91.9\%). Additionally, officers or communities that provide abundant information about population issues are friends, neighbors, and relatives (72.8\%). Furthermore, formal educational institutions, including schools (47.8\%), and community organizations (youth organizations, PKK/Family Welfare Program, Integrated Health Service Post, and religious organizations) $(49.6 \%)$ provided information.

Conclusions: In conclusion, efforts to increase the knowledge about population issues can be done by optimizing the function of television, close circles, the role of formal educational institutions and social organizations.
\end{abstract}

\section{Introduction}

Today, the diversity of population problems, especially unemployment, is a common obstacle to progress. The Omnibus Law on Job Creation, created by the Government, is a breakthrough in handling labor issues. This law answers the demands for harmonization and synchronization of overlapping, contradictory laws, and obstacles in the investment process, which is a source of industrial conflict. ${ }^{1}$ Moreover, poverty is another problem facing the population, which has been a drawback to development. Despite the government's efforts to reduce poverty, it has not been alleviated yet. Therefore, to overcome the problems, there is a need for coordination by the Central, Provincial, and Regional Governments. $^{2}$

Labor issues, unemployment, and poverty, which are high in Indonesia, are all acknowledged by families. ${ }^{3}$ The role of family and community in solving population problems, namely forming quality families and communities. And subsequently can improve the competitiveness of Indonesian society. Thus, population problems, especially labor and poverty problems can be overcome more optimally. ${ }^{4}$ Employment problems stem from an increased workforce that is not accompanied by economic absorption capacity, employment opportunities, and labor productivity. Indonesia's workforce growth has not been followed by employment growth or the supply and demand for labor. This situation has been exacerbated further by population structure, whose productive age or the demographic bonus has increased. However, employment problems can be overcome by optimizing and empowering people to have high bargaining power as employees. Moreover, there are efforts to increase labor productivity through targeted education and training of productive age. ${ }^{5}$ Therefore, there is a need for cooperation to overcome these interrelated population problems that can lead to poverty. ${ }^{6}$ Diverse population problems such as unemployment and poverty require accurate mapping to overcome them. Therefore, several initiatives to mitigate these problems can be well-planned and implemented according to the needs and experiences of the Indonesians. Such initiatives aim at improving the quality of human life through developing and strengthening rural and peripheral areas. ${ }^{3}$ Moreover, mapping population problems based on the needs of the people creates initiatives to effectively and efficiently address them. Development based on potential and conditions of the local population, population as a focal point, subject and object in the development process, development aimed at improving the quality of human resources, is the meaning of population-oriented development. ${ }^{7}$ Population-oriented development followed by the development of population-oriented policies can be a systemic guide to shaping humans with life skills, personal skills, academic and vocational skills. ${ }^{8}$

Population problems will be resolved by planning develop-

Significance for public health

Family knowledge about population issues is used by the Government to analyze, map, and determine development programs, including education, health, welfare, and the needs of the target community. This analysis also forms the basis of mapping and initiating an effective, efficient, and targeted development program. This paper explores the root of family knowledge for the Provincial Government to analyze and map population problems. 
ment based on population impact analysis and socialization, and main designs for control of population quantity and quality. Analysis of the impact of population including the impact of labor, environment, education, health, and resource availability. Control of population quantity and quality focuses on controlling the amount, structure, and location of population growth using a life cycle approach. ${ }^{9}$ The context of this population research aims to determine family knowledge of population issues, which can form a basis for the Provincial Government's analysis and mapping of these problems. Therefore, all programs meant to address these issues are implemented according to the needs of the population.

\section{Design and Methods}

This research used descriptive quantitative methods with a secondary data analysis (SDA) approach performed on quantitative data. Moreover, secondary data analysis (SDA) was performed based on knowledge, information sources, and the role of officers and community institutions on population issues contained in the 2019 Performance and Program Accountability Survey (SKAP) of Population of KKBPK (Population of Family Planning and Family Development), Central Java Province. The stages involved in secondary data analysis include determining and collecting sources of knowledge and information, and the role of officers and community institutions on population issues; normalization or clearing of required data; data analysis using computer applications (SPSS, SAS, or STAT); and reviewing related references.

The stages of the grounded approach used in this research include: a collection of knowledge, the use of information sources, the role of officers and community institutions on population issues from the 2019 SKAP data, reviewing and examining the collected data, and analyzing various aspects of related variables expected in this research. The research results are presented as descriptive and interpretation of the analyzed variables. The research respondents were families in the 2019 SKAP who met the requirements and agreed to be interviewed. Therefore, the number of respondents in the 2019 SKAP study was 11044 .

\section{Results and Discussions}

According to the results from the secondary data analysis of the 2019 Performance and Program Accountability Survey (SKAP) of the Population of KKBPK (Population of Family Planning and Family Development), Central Java Province on population issues knowledge, $51.5 \%$ of respondents had good knowledge of population issues. The above-average knowledge base was $66.17 \%$. Based on the survey, respondents' knowledge of population issues includes population explosion (44.6\%), migration $(81.4 \%)$, transmigration $(80.0 \%)$, urbanization $(65.9 \%)$, birth/fertility $(39.7 \%)$, death/mortality (42.9\%), morbidity (42.9\%), unemployment $(95.5 \%)$, employment $(97.1 \%)$, environmental damage $(88.3 \%)$, poverty $(97.1 \%)$, energy crisis $(69.2 \%)$, moral/social crisis $(64.4 \%)$, and demographic bonus (17.0\%). However, based on respondents' knowledge, the most concerning problems include unemployment, employment, and poverty. Moreover, respondents obtained knowledge of these issues from various information sources, including radio $(10.3 \%)$, television $(91.9 \%)$, newspapers $(16.1 \%)$, magazines/tabloids $(9.8 \%)$, pamphlets/leaflets/brochures (9.5\%), flipcharts $(3.8 \%)$, posters $(20.9 \%)$, signs $(22.8 \%)$, banners (11.2\%), billboards $(9.9 \%)$, exhibitions $(2.8 \%)$, websites/internet $(21.1 \%)$, Community Service Vehicle of Family Planning $(1.8 \%)$, murals/wall paintings/graffiti (4.2\%), and other sources (3.9\%).

Officers or the community were also sources of information on population issues, including PKB (Family Planning Counselor)/PLKB (Family Planning Field Workers) (2.2\%), teachers $(46.3 \%)$, religious leaders $(12.0 \%)$, community leaders $(20.8 \%)$, doctors $(6.6 \%)$, midwives/nurses $(14.8 \%)$, village officials (21.0\%), PPKBD (Supervisors Maid Village Family Planning) /sub-PPKBD/ cadres (21.4\%), friends/neighbors/relatives $(72.8 \%)$, and other sources $(6.5 \%)$.

Respondents' knowledge of population issues was obtained from both formal and non-formal institutions. These institutions include formal education; (school) (47.8\%), and non-formal education (courses, tutoring, Islamic boarding school, etc.) $(2.1 \%)$, community organizations (youth organizations, PKK/Family Welfare Program, Aisyiyah, Fatayat NU, Integrated Health Service Post, etc.) (49.6\%), community groups (communal Quran reading, Sunday school, mosque youth, Christian youth fellowships, etc.) (23.8\%), activity groups (Toddler Family Development, Teenager Family Development, Older Family Development, Income Enhancement of Welfare Family, Information Center and Counseling for Teenagers) (1.6\%), and other institutions $(20.4 \%)$ (Table 1). Secondary data analysis on population knowledge shows respondents are knowledgeable about population issues. The main issues include employment, unemployment, and poverty. Moreover, the issues are both social and economic problems.

Both economic and social life have had a paradigm shift from a resource-based to a knowledge-based or creativity-based economic life. This paradigm shift will affect the demand and supply of skilled laborers who support positive economic growth. However, unskilled labor will increase unemployment and poverty levels. Improvement of labor quality is carried out through formal and informal institutions. Formal institutions include the provision of education for labor through schools, vocational schools, and courses. Informal institutions include vocational training, internship, improvement of mental and spiritual quality, a program for improving nutrition and quality of health through seminars and workshops. ${ }^{10}$

Furthermore, the program of improving labor quality is followed by strengthening national with global economic integration, equitable distribution of resources that support labor productivity and capital effectiveness, the intensive provision that encourages companies to invest and innovate, adequate work facilities, and suitability of work fields. ${ }^{11,12}$

Improvement of labor quality will affect labor competitiveness and productivity. Low quality of labor cause low productivity and decrease labor competitiveness. ${ }^{13}$ Improving the quality of labor is an effort to overcome the problem of unemployment. Labor quality is resolved individually or collectively, and a multidimensional problem. The success of improving the quality of labor is an indicator of improving the quality of the population, the progress of a community or nation, and the success of development. ${ }^{14}$

The initiative to overcome employment and unemployment issues is by developing Micro, Small, and Medium Enterprises (MSMEs). Through training and mentoring within a certain period, the population can create jobs in the form of MSMEs. Therefore, the success of the MSMEs program can overcome unemployment, which indirectly affects poverty levels. ${ }^{15}$ The unemployment problem is influenced by several demographic conditions in Indonesia. These conditions include demographic bonus, globalization, and regional superiority potential. Unemployment in Indonesia is basically due to the relatively low competitiveness of workers, low labor market, government's industrial relations, indecent labor and companies, low supervision and protection of workers, and skills mismatch between firms and workers (link and match). ${ }^{16}$ 
Consequently, unemployment has caused high poverty levels in Indonesia, which are influenced by education, health, economic growth/funding, and state income. Therefore, initiatives to reduce poverty are correlated to unemployment reduction programs. As such, they have launched programs to increase Indonesia's human resources by offering quality education and providing health insurance. These are meant to improve the quality of Indonesia's population towards economic growth. ${ }^{17-19}$

Knowledge of population issues needs to be shared with Indonesian people. This will influence efforts to address population problems in a planned, systematic, and comprehensive manner. Furthermore, population issues must be known by all Indonesians because they are universal and have a broad spectrum in the management of human life. Government programs regarding population issues hinge on its schooling system. Through schooling, integration of population material content, family planning, and development can be incorporated into subjects. Efforts to incorporate knowledge of population issues in schools prepare the youth for a holistic life, which will shape the next generation with national character and quality. ${ }^{20}$ The data shows that schools, as formal institutions, are the main information sources for respondents concerning population issues. Schools provide education on population issues, which can increase the knowledge, awareness, and skills of the community. Therefore, people can deal with population problems and provide insights into solutions. ${ }^{21}$ Non-formal institutions were also used by respondents as information sources. They include youth social organizations such as PKK, Aisyiyah, Fatayat NU, Integrated Health Service Post, and other community organizations. Community organizations are established based on similar aspirations, desires, and needs as Pancasila that aims to participate in the development objectives of the Republic of Indonesia. ${ }^{22}$

Social organizations serve as community development forums to succeed in developmental projects, including information distribution on population issues. Through these organizations, people acquire knowledge, understanding, and skills related to the development of population issues. Therefore, people are adequately equipped to deal with population issues. ${ }^{22}$ Furthermore, community organizations are part of Indonesian culture, which fosters cooperation for mutual prosperity. Moreover, people get more confident when dealing with problems in their close circles. Formal and informal institutions are used by the community as an institution for the establishment and strengthening of human resources characters and ways of preparing the community to overcome population issues, as well as political, economic, and social problems. ${ }^{23}$

From the secondary data analysis, Indonesian obtained information on population issues from close circles such as friends, relatives, or neighbors. Additionally, people widely used television as a source of media information. Furthermore, Indonesian have access to television media because there is a rapid development of social media technology. This helps them enjoy TV shows through the broadcast schedule and access online TV shows anytime, anywhere. Moreover, broadcast content in television media has been strictly regulated and supervised. Therefore, people feel more comfortable using television as a source of media information. ${ }^{24}$ Television functions in development as an information media to improve community understanding and knowledge, especially in population problems. ${ }^{25}$ Information media in development is community communication media to realize changes or revolutions characters that support development. ${ }^{26}$
Table 1. Distribution of knowledge frequency, information sources, officers and institutions providing information on population issues based on the Performance and Program Accountability Survey 2019 data for Central Java Province (total respondents: 11044).

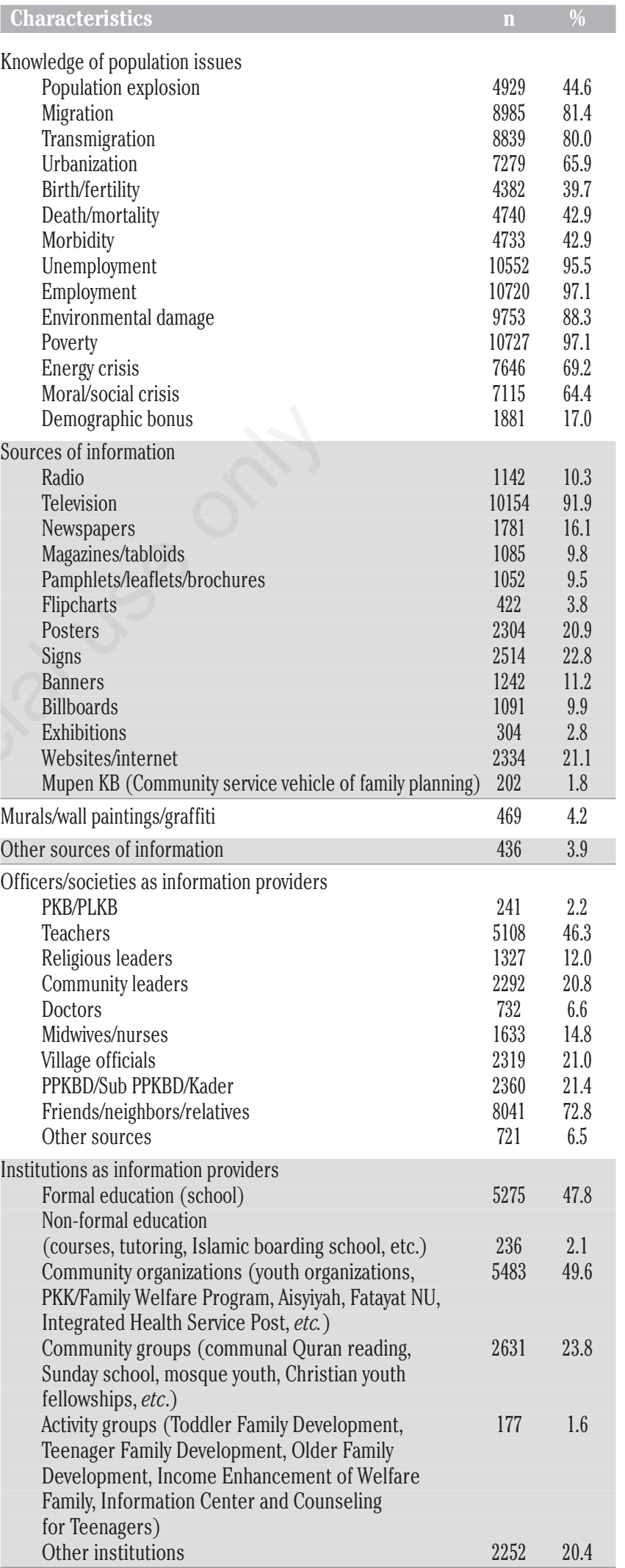




\section{Conclusions}

Knowledge of population issues widely known by respondents includes employment, unemployment, and poverty. Knowledge of population issues can be obtained through information from the closest people and media. Lastly, information on population issues can be obtained from formal and non-formal institutions with a comprehensive and synergic pattern.

Correspondence: Mujahidatul Musfiroh, Center for Population and Gender, LPPM UNS, Surakarta, Jalan Ir. Sutami 36 A. Kentingan Jebres Surakarta Jawa Tengah, Indonesia.

Tel. +62.271632368 - Fax: +62.271632916.

E-mail: mujahidatul_m@staff.uns.ac.id

Key words: Family; knowledge; population issues.

Contributions: All authors contributed equally to this article.

Conflict of interests: The authors declare no potential conflict of interest.

Funding: The authors independently financed this research.

Ethical Approval: This research was reviewed by the dr. Moewardi Hospital Ethics Committee, Surakarta, Indonesia.

Acknowledgments: This article is a secondary data analysis from the 2019 Performance and Program Accountability Survey (SKAP) of the Population of KKBPK (Population of Family Planning and Family Development), Central Java Province. The owner permitted the authors to further analyze and publish the data. This study was independently funded and is a result of the active independent teaching staff at Universitas Sebelas Maret. Furthermore, this publication is a collaboration between the Center for Population and Gender Studies, Institute for Research and Community Service, Universitas Sebelas Maret, and the National Family Planning Coordination Board (BKKBN) of Central Java Province. The authors expressed gratitude to their colleagues from the BKKBN of Central Java Province for allowing analysis of the 2019 SKAP data on knowledge of population issues.

Conference presentation: Part of this study was presented at the $1^{\text {st }}$ International Nursing and Health Sciences Symposium, November $13^{\text {th }}$ to $15^{\text {th }} 2020$, Brawijaya University, Malang, Indonesia.

Received for publication: 14 January 2021.

Accepted for publication: 21 March 2021.

(Copyright: the Author(s), 2021

Licensee PAGEPress, Italy

Journal of Public Health Research 2021;10:2226

doi:10.4081/jphr.2021.2226

This work is licensed under a Creative Commons Attribution NonCommercial 4.0 License (CC BY-NC 4.0).

\section{References}

1. Ruhyani Y. [Problematika dan Tantangan Kependudukan Indonesia di Tahun 2020 (Indonesian population problems and challenges in 2020)].[Article in Indonesian]. Jakarta: Indonesian Institute of Sciences; 2020.

2. Raharjo DB. [10,80 Persen Penduduk Jateng Masih Miskin, Ini Langkah Pemprov - 10.80 percent of Central Java's population is still poor, this is the Provincial Government's step].[in
Indonesian]. 2019. Accessed: 2020 Oct 15. Available from: https://jateng.suara.com/read/2019/10/14/074944/1080persen-penduduk-jateng-masih-miskin-ini-langkah-pemprov?page $=$ all

3. Rahmadewi, Nasution SL, Ekoriano M, et al. [Survei Kinerja dan Akuntabilitas Program KKBPK (SKAP) 2019 (2019 KKBPK program performance and accountability survey (SKAP)].[in Indonesian]. Jakarta: Center for Family Planning and Family Planning Research and Development, National Population and Family Planning Agency; 2019.

4. Office of Communication and Informatics of Blora Regency. [Menjadikan Pendudukan dan Keluarga Titik Sentral Pembangunan (Making occupation and family the central point of development)].[in Indonesian]. 2018. Accessed: 2020 Oct 10. Available from: https://blorakab.go.id/index.php/ public/berita/detail/682/menjadikan-penduduk-dan-keluargatitik-sentral-pembangunan

5. Welianto A. [Masalah Ketenagakerjaan di Indonesia (Labor problems in Indonesia)].[in Indonesian]. 2020. Accessed: 2020 Oct 10. Available from: https://www.kompas. com/skola/read/2020/07/14/154500069/masalah-ketenagakerj a a n-di - indones i a ? p a g e = a $11 \#: \sim$ : t e x t $=$ Permasalahan\%20klasik\%20yang\%20muncul\%20di,jumlah\%20penduduk\%20yang\%20siap\%20kerja

6. Dewi DK. [Keterkaitan Pengangguran dan Kemiskinan di Sumatera Utara - The linkage of unemployment and poverty in North Sumatra].[in Indonesian]. 2020. Accessed: 2020 Oct 10. Available from: https://waspada.co.id/2019/12/keterkaitanpengangguran-dan-kemiskinan-di-sumatera-utara/

7. Hardiani, Junaidi. [Analisis Kuantitas dan Kualitas Penduduk sebagai Modal Dasar dan Orientasi Pembangunan di Provinsi Jambi (Analysis of population quantity and quality as basic capital and development orientation in Jambi Province)].[in Indonesian]. 2011. Accessed: 2020 Oct 10. Available from: https://repository.unja.ac.id/188/1/analisis_penduduk_junaidi.pdf

8. Sintong M. [Kebijakan Berwawasan Kependudukan dan Peningkatan Kualitas Sumber Daya Manusia - Populationbased policies and improving the quality of human resources].[Article in Indonesian]. Jurnal Geografi 2013;5:1730 .

9. Tjiptoherijanto P. [Kependudukan Indonesia dalam Pembangunan Pasca (Indonesian population in post development)].[in Indonesian]. 2015. Jakarta: Deputy for Population Control and Central National Family Planning; 2013.

10. Rinaldi. [Strategi Peningkatan Kualitas dan Profesionalitas Tenaga Kerja dalam Menyongsong MEA 2015 (Strategies for improving the quality and professionalism of workers in welcoming the AEC 2015). Proceedings National Seminar of the Faculty of Social and Political Sciences, Open University].[in Indonesian]. 2015 Accessed: 2020 Oct 10. Available from: http://repository.ut.ac.id/3199/1/fisip2015_02_rinaldi.pdf

11. Adianto J, Fedryansyah M. [Peningkatan Kualitas Tenaga Kerja dalam Menghadapi ASEAN Economy Community (Improving the quality of workers in facing the ASEAN economy community)].[Article in Indonesian]. Jurnal Pekerjaan Sosial 2018;1:77-86.

12. Daraba D, Subianto AB, Salam R. [Upaya Peningkatan Kualitas Tenaga Kerja pada Dinas Ketenagakerjaan di Kota Makassar (Efforts to improve the quality of workers at the manpower office in Makassar City)].[Article in Indonesian]. Jurnal Pemikiran dan Penelitian Administrasi Publik 2018;8:21-6.

13. Adam L. [Membangun Daya Saing Tenaga Kerja Indonesia 
Melalui Peningkatan Produktivitas (Building the competitiveness of Indonesian workers through increased productivity)].[Article in Indonesian]. Jurnal Kependudukan Indonesia 2016;11:71-84.

14. Pranadji T, Sumaryanto S, Gunawan E. [Penduduk, Pertanian, Ketenagakerjaan dan Bahaya Pengangguran dalam Pembangunan (Population, agriculture, employment and the danger of unemployment in development)].[Article in Indonesian]. Analisis Kebijakan Pertanian 2013;11:89-106.

15. Dongoran FR, Nisa K, Sihombing M, et al. [Analisis Jumlah Pengangguran dan Ketenagakerjaan terhadap Keberadaan Usaha Mikro Kecil dan Menengah di Kota Medan (Analysis of the number of unemployment and employment on the existence of micro, small and medium enterprises in Medan City)].[Article in Indonesian]. Jurnal Edutech 2016;2:59-72.

16. Wijayanto H, Ode S. [Dinamika Permasalahan Ketenagakerjaan dan Pengangguran di Indonesia (Dynamics of employment and unemployment problems in Indonesia)].[Article in Indonesian]. Administratio 2019;10:18.

17. Zahra A, Fatin A, Afuwu H, et al. [Struktur Kemiskinan, Indonesia: Berapa Besar Pengaruh Kesehatan, Pendidikan dan Kelayakan Hunian? (Poverty structure, Indonesia: How much does health, education and housing worthiness affect?)].[Article in Indonesian]. Jurnal Inovasi Ekonomi 2019;4:67-74.

18. Wahyudi D, Rejekingsih TW. [Analisis Kemiskinan di Jawa Tengah (Poverty analysis in Central Java)].[Article in Indonesian]. Diponegoro Journal of Economics 2013;2:1-15.

19. Puspita DW. [Analisis Determinan Kemiskinan di Provinsi Jawa Tengah (Analysis of the determinants of poverty in Central Java Province)].[Article in Indonesian]. Jejak 2015;8:100-7.
20. Darwis D. [Pentingnya Pendidikan Kependudukan bagi Penduduk Usia Muda dalam Kerangka Pembangunan Karakter Bangsa (The importance of population education for young populations in the framework of national character building)].[in Indonesian]. Jakarta: National Population and Family Planning Agency; 2017.

21. Husin A. [Peranan Pendidikan Kependudukan terhadap Pelestarian LIngkungan Hidup (The role of population education in environmental conservation)].[Article in Indonesian]. DeJoS 2013;1:14-9.

22. President of the Republic of Indonesia. [Law of the Republic of Indonesia Number 17 of 2013 concerning Community Organization].[in Indonesian]. 2013. Accessed: 2020 Oct 10. Available from: https://konsillsm.or.id/wp-content/uploads/ 2013/10/UU-17-2013-ttg-Organisasi-Kemasyarakatan.pdf

23. Inanna. [Peran Pendidikan dalam Membangun Karakter Bangsa yang Bermoral (The role of education in building a moral national character)].[Article in Indonesian]. Jekpend 2018;1:27-33.

24. Abdullah A, Puspitasari L. [Media Televisi di Era Internet (Television media in the age of the internet)].[Article in Indonesian]. ProTVF 2018;2:101-10.

25. Tucunan AAT, Maitimo BI. [Peran Sumber Informasi Media Massa dan Media Luar Ruang terhadap Pengetahuan tentang Kependudukan Penduduk di Sulawesi Utara (The role of mass media and outdoor media information sources on knowledge of population in North Sulawesi)].[Article in Indonesian]. Jurnal Keluarga Berencana 2018;3:45-56.

26. Suri D. [Pemanfaatan Media Komunikasi dan Informasi dalam Perwujudan Pembangunan Nasional (Utilization of communication and information media in realizing national development)].[Article in Indonesian]. Jurnal Komunikasi Pembangunan 2019;17:177-87. 